This is an electronic reprint of the original article. This reprint may differ from the original in pagination and typographic detail.

Author(s): Maunula, Minna

Title: Highest Academic Educational Expertise and Working Career

Year: $\quad 2016$

Version:

Please cite the original version:

Maunula, M. (2016). Highest Academic Educational Expertise and Working Career. In INTED 2016 Proceedings : 10th International Technology, Education and Development Conference (pp. 6499-6504). IATED.

https://doi.org/10.21125/inted.2016.0533

All material supplied via JYX is protected by copyright and other intellectual property rights, and duplication or sale of all or part of any of the repository collections is not permitted, except that material may be duplicated by you for your research use or educational purposes in electronic or print form. You must obtain permission for any other use. Electronic or print copies may not be offered, whether for sale or otherwise to anyone who is not an authorised user. 


\title{
HIGHEST ACADEMIC EDUCATIONAL EXPERTISE AND WORKING CAREER
}

\author{
Maunula Minna \\ University of Jyvaskyla, Kokkola University Consortium Chydenius (FINLAND)
}

\begin{abstract}
$21^{\text {st }}$ century skills are multidimensional and highly demanding, especially in highest academic level. Academic education is facing new challenges and expectations which are set e.g. by working life and individuals in academic contexts. Universities are trying to balance between new demands and older academic traditions.

Individuals in highest academic contexts are facing global change and requirements in their everyday life. Academic education should enable participation in working life and give good generic and field specialized skills. The highest academic education and working life do not share the same understanding of expertise skills.

In my paper I will discuss the highest academic education through individual experiences. How academic students evaluate their generic and specialized skills and their employability? How different working life careers are constructed? What skills can be constructed in academic contexts and what other skills are needed in $21^{\text {st }}$ century?
\end{abstract}

Keywords: Academic education, educational expertise, working career.

\section{STARTING POINTS FOR ACADEMIC EDUCATION AND EXPERTISE}

$21^{\text {st }}$ century and the quick change cycle challenge the education system in many ways. The task of transforming the expertise of education is challenged by many factors in the academic context [1] and the tradition of education which is based on research is being left aside. The temptation of a shortcut is a danger in the pursuit of innovations. The highest expert education, doctoral education, is also concerned with continuously increasing expectations [2] and, on the other hand, tightening resources [1].

The expert and skillful labour force is globally considered as valuable capital and investment. The working life is changing at a fast pace which touches all the stake holders in the working life. Also the workers have had to change their ways of thinking and their ways of operation. The linear work career in the employment of one employer is history. Before the work career developed and proceeded according to a certain logic progressively and as a result of the exertions of the individual [3]. Nowadays the working life consists of unconnected and unpredictable short periods. More and more the individual and comprehensive skills are emphasized, and the work in its traditional form is only one sector.

The work career is individual, random and comprehensive. The work and other sectors fasten seamlessly to one another and to the wholeness of the life course [4]. In spite of the ideas which have changed, or perhaps because of them, the difficulty in anticipating the future, and responsibility and freedom which are given to the individual are distressing. The hard values of the financial world prevail in the working life, humanity and caring are increasingly rare. The work and a constant new learning bring meaningfulness, welfare and comprehensive development but also the compulsion to compete and succeed to the life of the individuals. [5.]

\section{HIGHER EDUCATION AND EMPLOYMENT}

The doctors' employment and the working life benefiting from the doctors are a current cause for the deliberations [6]. The objective of the highest academic education is to produce high level expertise which can be utilized in different contexts [7]. The academic expertise is built over many years and gets different individual stresses according to, for example, the emphases of the discipline, the individual contexts and work orientation. The doctors' expertise is generic and field-specific as well as having a deep knowledge of their own research subject [8]. 
Contrary to the traditions, the graduating doctors to an increasing extent move to expert assignments outside the university. The broadening skills expectations which are directed to the doctors have been realized in the doctoral education [7], and the different elements which increase skills in projects and entrepreneurship have been added to doctoral education. Internationalism and closer working life contacts are starting points for the high quality expert education. In addition to the numerous changes and the increasing quality criteria the doctoral students also have different expectations of the expert education [9].

During their studies, the doctoral students learn many things which are dimensions of both the personal and social learning [8]. Effectiveness demands are connected to the doctoral studies as it is generally the case also with working life. The expectations in the working life which are directed to the doctors are generic expert skills [10] which are not academic researcher skills but multidimensional communicative skills, networking and ability to work in a team. In addition to specific expert skills, the doctors have generally useful skills: good problem solving skills, systematic working method, innovativeness and understanding of the commercial possibilities of research results. The doctors can popularize their research results and command large concepts. The awareness of the current matters, ability to think strategically as well as networking and social skills are developed during the doctoral process [9]. The more defined definition of the skills objectives of doctoral studies would also convince the non-academic sectors and employers of the doctors' competence even though the definition of the skills is not an easy task [11]. Every doctor has individual skills and presenting them in a way that is interesting to the working life is essential. Different doctors have different skills backgrounds and their own individual expectations for their future work career.

\section{METHODOLOGY}

The research material consisted of loosely themed and narrative interviews of 12 under-40-year-old female doctoral students. The examination combines the changes that are met by the society, scientific field and individuals and which connect the macro and micro levels. The individual experience is in a central role in this article, which the phenomenological research tradition proceeds. The individual experience has a context where it takes place, it is interpreted and understood in the spirit of the hermeneutic dialogue. In the center of the examination are the individually interpreted experiences of the female doctoral student, highest academic educational expertise and working career. The stories told by doctoral students convey the temporal nature of the lifecourse [12] as well as the cumulative nature of the forming understanding. Interpreting the narrative story of the studies is a journey of exploration to the past and at the same time a glimpse in to the future [13]. In order to reach understanding, one needs to know the past and the present and to predict the future [14].

The theme interviews were well suited to connecting the doctoral studies and the experiential nature of educational expertise and working career. The stories formed and conveyed experiences of the experienced and interpreted reality [also 13]. The wholeness is not simple and clear but through processing by themes the interaction, tensions and also the contradictions of different areas were individually brought out [see 13]. The doctoral students' stories proceeded narratively, temporally and thematically constructing an intelligible wholeness, but simplifying the reality. The past is understood, the present is analyzed and the future is anticipated by telling the lifecourse story again and again [12; 14]. The analysis of the material was the content analysis of themes which develop hermeneutically.

The work careers of the female doctoral students in my study were varying in many aspects, age being one reason as the age distribution of the students participating in the study was between 25 - 38 years. All of the women in my study had been in the working life. Their work assignments had been diverse, for example: cleaning, cashier, customer service, bookkeeping, office work, bank employee, factory worker, restaurant worker, trainee of Master of Arts studies, leader of the sports club, kindergarten teacher, different teaching tasks, workplace trainer, assistant and researcher. Furthermore, the students who participated in the study had all been on the payroll in a university during their work history.

\section{EDUCATION, WORK EXPERIENCE AND GROWING CAREER AWARENESS}

\subsection{First stage of the education}

The majority of the doctoral students in my study had initiative in finding out about the possibility of doctoral studies and in applying for the studies. They were inspired by an in-built desire to know and to 
understand an interesting study subject, a desire to know and study more as well as by the new challenges and curiosity. The female doctoral students emphasized that the meaningful study subject was promoting their commitment to the research work [also 4].

According to my study, the beginning motives and objectives of doctoral studies were manifold and individual. However, the motivations developed as the studies proceeded. The doctoral students' objectives and career plans reflected their operation in the doctoral thesis process. From the point of view of the individual, the objectives overlapped with the individual contexts and perspectives of the future taking shape, the organizational objectives and aims directing for the effectiveness at a larger scale did not direct operation at the individual level. The doctoral students' awareness of their own motives, of the realities of the doctoral education and of the future possibilities with a doctoral degree is central so that the long-term education would be rewarding and useful [also 9]. Connecting the personal starting points and objectives of the doctoral students more tightly as a part of the curriculum to be drawn up would indeed be a matter worth developing [also 7].

\subsection{Structuring of own skills and expertise}

Finding the reasons for beginning the doctoral process from the elements of the research or other expert work of one's own field, from the core of the actual work, increased the profound commitment also in difficult situations according to my study. The conditions became more promising if the interest in the contents of the research was there first and after that other conditions were organized to be as favorable as possible. The significance of other factors of life was also emphasized, concentrating only on the research was not regarded as a good thing by the doctoral students participating in the study. The research work required long-term preoccupation and commitment, it cannot just be carried out. The topicality of the subject of the doctoral thesis, the personal processing and delimitation of the subject were regarded as the conscious and meaningful solutions.

The advantages gained from graduating with a doctoral degree are weighed in relation to the contribution [e.g. 4]. Why are the students ready to invest time, energy and money in the doctoral studies? The interest in the research subject and experience of the personal development are essential. These are partly in conflict in respect to the global development trends of the research activities: more and more often the study subjects are ready small parts of larger projects and a ready framework is set for the work [6]. The consideration of the importance of the subject, the acquisition of financing and one's own reflection stay in the margins, as well as a personal touch and commitment.

Without personal and profound devotion it is possible that in the future the doctoral students expect the external control and financing still more strongly. At the same time one can consider how the ability for innovation appreciated in the working life and in the research will develop if the doctoral students do not utilize and refine their creativity in the different turning points of the doctoral process, for example, the necessity of the subject and the wider context do not even need to be thought about.

\section{GENERIC SKILLS AND EMPLOYABILITY}

\subsection{The significance of the accumulated work experience}

The doctoral students of my study were divided into two groups for the work experience: to the ones who had worked hard at different jobs already during the studies and to the ones who had acquired plenty of work experience later on. Work experience of the another group was narrow and limited to the work practice of the university studies and a few summer jobs. The work history of the latter group was considerably smaller and contacts to working life weaker. The students participating in the study evaluated all work experience to be significant and educational. The direction of the work career took shape already early on with the different work experiences. It was seen that the work in the past was defining even the future assignments. The different work assignments and studies formed the individual wholeness with which the expertise began to take shape. The work experience acquired during the studies eased the move to the working life and strengthened attachment to it.

Short, that I have not done this work at all (own field), well some during the practice, so that is the experience of my own field and then some very different summer jobs. But not a lot.

I have worked since the high school, in addition to school and studies, for years. Then I went abroad (for years). I returned to Finland, I probably did too much other work also while I was doing my thesis. The work has continued all the time. I wanted to work abroad, and I have 
achieved that, I'm not longing to be there anymore. I'm really satisfied that I was able to make it. It was so big a thing for me, I appreciate it a lot.

The students having plenty of work experience were satisfied as a whole with their doctoral studies and with the narrow work experience the uncertainty towards the doctoral studies increased. Some of the female doctoral students in my study intended to also work in more practical assignments in addition to the doctoral studies so that the link on to the working life would be preserved. Some had planned their thesis research so that it could be flexibly linked to the different work assignments of their own field and their own skills could be utilized widely.

The female doctoral students in my study wanted to develop professionally and to widen their job opportunities. With graduating with the doctoral degree, the most common wish and objective was to get the qualifications of the researcher and possibility to continue further the inspiring research work.

\subsection{From the doctoral studies to be an expert in working life}

There was variation in the structuring of the doctoral studies and of working life between the female doctoral students in my study. For some it was clear that the work career that was already built was significant and the doctoral studies could be used to direct and to strengthen the work career further [also 5; 15]. Some of the women in the study hoped that the doctoral studies would open a work career and some could not yet see the connection between them. The successful choice of subject of the doctoral thesis can also be used to promote one's own employment [9].

I think that it is my work, not studying, I have worked and then in the end I get the doctoral degree. It is difficult to think, that I am a student and it is also to do with the fact that I have been continuously in paid employment, I am very work orientated. I have not made economic sacrifices because I have done it as paid work.

The doctoral students evaluated themselves from many angles as workers and realized their own strengths and weaknesses. Some had learned a more efficient working method consciously. The women of my study experienced their own working method as the continuum of their personality, if one was also usually precise and pedantic, the same features were present in them as workers. They described themselves as diligent, inspired and active in cooperation. Some of the doctoral students realized that they were downplaying themselves and their skills.

The women in my study who were furthest in their doctoral studies talked at length about employment and the worries which are related to it. They were aware of the sizeable expectations of the working life which caused them pressure.

I attempt to increase my value in the labour market. The future employment has distressed me, where I am going to be employed and what I could do. I started to think that maybe I expand my skills. If you think about our labour market, then there is a lot of project administration and leading and planning, marketing, so I should also have business skills.

In spite of the doubts and uncertainties the overall evaluation of the doctoral process and of being a future doctor was more strongly positive than negative for the female doctoral students in my study. The understanding of completing the doctoral thesis varies from the product to the development process of expertise [16]. According to my interpretation, the stronger orientation of the doctoral student to the future assignments would help to perceive the process in the longer term. Every individual has a need to learn and a desire to develop, which also becomes true in the doctoral studies [9]. The different alterations of the course of the work career, breaks and the individual adjustments are everyday life in the modern society.

The primary objective regarding work for all the women in my study was meaningful work. The traditional idea of the professional identity has broken and the expert role has emerged instead, the role that is based on the individual skills capital, is transforming and is to be added to continuously [17]. The female doctoral students in my study believed that getting employment in the meaningful work assignments required tough competition. The education does not guarantee or facilitate employment but instead overcrowding adds challenges of the academically educated [18], such as the employment difficulties. The women of my study evaluated that the different research projects would be the most probable employer, they also considered teaching and development assignments as good alternatives. According to my study, the female doctoral students were confident that their high quality and persistent working would lead to employment which is in accordance with their merits. 


\section{CONCLUSION}

Highest academic educational expertise and working career are both in a new situation in the quick change cycle of 21 st century. The continuously increasing and changing skills demands are also directed to the academic elite. The traditions of employment are crumbling and require an updating of awareness. The unstable labour market and the new kinds of employments challenge doctors also at the individual level. The doctoral education makes it possible to acquire the broad expert skills but still the investment needs an input in selling the skills. In this study the work career subsequent to the doctoral education appeared as a special challenge but it was not known how to intervene with it concretely. Furthermore, the general attitude to the doctors in the working life outside the academic contexts was regarded as one of shunning and would require concrete actions in a larger context.

According to my study, the doctoral students themselves experience increasing skills demands which are directed at the doctors both as a challenge and a burden. According to them, the development of the expertise is rushed in tight and uncertain conditions [also 18]. Their own skills were pinpointed as expertise and generic skills but finding employment following the doctoral degree in the assignments which correspond with the education appeared as a major challenge. The expertise built up in the doctoral studies is capital which one wants to utilize in genuine contexts. Finding employment with a doctoral qualification appeared as continuing and increasing competition on the experts' tightening labour market. The traditional expert education is no longer enough to correspond with the assignments which require versatile expert skills, - the future doctors need even more versatile and adaptable expert and generic skills than at present and the ability for continuous transformation.

\section{REFERENCES}

[1] Ursin, J., Aittola, H., Henderson, C. \& Välimaa, J. 2010. Is education getting lost in university merges? Tertiary Education and Management 16 (4), 327-340.

[2] Tymon, A. 2013. The student perspective on employability. Studies in Higher Education 38 (6), 841-856.

[3] Beck, U. 2000. The brave new world of work. Cambridge: Polity Press.

[4] Leonard, D., Becker, R. \& Coate, K. 2005. To prove myself at the highest level: The benefits of doctoral study. Higher Education Research and Development 24 (2), 135-150.

[5] Neumann, R. \& Tan, K. K. 2011. From PhD to initial employment: the doctorate in a knowledge economy. Studies in Higher Education 36 (5), 601-614.

[6] Leonard, D. \& Becker, R. 2009. Enhancing the doctoral experience at the local level. Teoksessa D. Boud \& A. Lee (toim.) Changing practices of doctoral education. London: Routledge, 71-86.

[7] Cumming, J. 2010. Doctoral enterprise: a holistic conception of evolving practises and arrangements. Studies in Higher Education 35 (1), 25-39.

[8] Hopwood, N. 2010. Doctoral experience and learning from a sociocultural perspective. Studies in Higher Education 35 (7), 829-843.

[9] Leonard, D. 2001. A Woman's guide to doctoral studies. Buchkigham: Open university press.

[10] Baker, V. \& Lattuca, L. 2010. Developmental networks and learning: towards an interdisciplinary perspective on identity development during doctoral study. Studies in Higher Education 35 (7), 807-827.

[11] Halse, C. \& Mowbray, S. 2011. The impact of the doctorate. Studies in Higher Education 36 (5), 513-525.

[12] Ricoeur, P. (1988). Time and Narrative. Transl. K. Blamey and D. Pellauer. Chicago: University of Chicago Press.

[13] Chase, S. E. (2005). Narrative Inquiry: Multiple lenses, approaches, voices. In N. K. Denzin \& Y. S. Lincoln (Eds.) The Sage Handbook of Qualitative Research. $3^{\text {rd }}$ ed. Thousand Oaks: Sage Publications, 651-680.

[14] Heidegger, M. (1996). Being and Time. Original: Sein und Zeit (1953). Transl. J. Stambaugh. Albany, New York: State University of New York. 
[15] Costley, C. \& Lester, S. 2012. Work-based doctorates: professional extension at the highest levels. Studies in Higher Education 37 (3), 257-269.

[16] Stubb, J., Pyhältö, K. \& Lonka, K. 2012. The experienced meaning of working with a PhD thesis. Scandinavian Journal of Education Research 56 (4), 439-456.

[17] Sennett, R. 1998. The corrosion of character: the personal consequences of work in the new capitalism. New York: Norton.

[18] Ylijoki, O.-H. 2013. Boundary-work between work and life in the high-speed university. Studies in Higher Education. 38 (2), 242-255. 